\title{
New petrographic, geochemical and geochronological data for the Reguengos de Monsaraz pluton (Ossa Morena Zone, SW Iberian Massif, Portugal)
}

\author{
Nuevos datos petrográficos, geoquímicos y geocronológicos \\ del plutón de Reguengos de Monsaraz \\ (Zona de Ossa Morena, SO del Macizo Ibérico, Portugal)
}

\author{
A. Antunes ${ }^{1}$, J.F. Santos ${ }^{1}$, M.R. Azevedo ${ }^{1}$, M.H. Mendes ${ }^{1}$, S. Ribeiro ${ }^{1}$
}

\begin{abstract}
The Reguengos de Monsaraz pluton is a late to post-tectonic Variscan intrusion occurring in the Ossa Morena Zone (Iberian Variscan Chain). The dominant lithological types are tonalites and granodiorites, but the internal area of the massif is composed of gabbro-dioritic rocks. Field evidence shows that the intrusion is heterogeneous at mesoscopic scale suggesting that the emplacement of mafic and felsic magmas was contemporaneous. Petrographic and geochemical studies reveal that the different lithologic types define a continuous sequence with compositions varying from metaluminous to slightly peraluminous and a typical calc-alkaline signature. In Harker variation diagrams, it is possible to observe systematic rectilinear correlations pointing to the involvement of magma mingling/mixing processes in the petrogenesis of this sequence. Rb-Sr isotopic data, using a mineral-mineral pair from a granodiorite sample, yielded an age of $298 \mathrm{Ma}$, interpreted as a cooling age after igneous crystallization.
\end{abstract}

Key words: Ossa Morena Zone, late to post tectonic intrusion, calc-alkaline magmas, mingling/mixing, $R b-S r$ geochronology.

\section{RESUMEN}

El plutón de Reguengos de Monsaraz es una intrusión varisca tardi- a post- tectónica localizada en la Zona de Ossa Morena (Cadena Varisca Ibérica). Los tipos litológicos dominantes son las tonalitas y las granodioritas aunque la zona mas interna del macizo está formada por rocas gabro-dioríticas. Las evidencias de campo muestran que todos los tipos litológicos son heterogéneos a escala mesoscópica y sugieren que el emplazamiento de los magmas máficos y félsicos fue contemporáneo. Los estudios petrográficos y geoquímicos muestran que los diferentes litotipos definen una secuencia continua con una afinidad calcoalcalina típica y composiciones variando desde metaluminosas a peraluminosas. En los diagramas de Harker se observan correlaciones rectilíneas sistemáticas, lo que sugiere que la mezcla de magmas tuvo un papel decisivo en su petrogénesis. Los datos isotópicos de $\mathrm{Rb}$-Sr, usando un par mineral-mineral de una granodiorita, proporciona una edad de $298 \mathrm{Ma}$, que se interpreta como la edad del enfriamiento posterior a la cristalización ígnea.

Palabras clave: Zona de Ossa Morena, intrusión tardi a post-tectónica, magmas calcoalcalinos, mezcla de magmas, geocronología Rb-Sr.

\section{Introduction}

The Reguengos de Monsaraz pluton is located in the Portuguese part of the Ossa Morena Zone $(\mathrm{OMZ})$, one of the major geotectonic units of the
Iberian Massif (Fig. 1). Based on structural and stratigraphic criteria, the Portuguese part of the $\mathrm{OMZ}$ was further subdivided into the following domains, from NE to SW: a) the Alter do ChãoElvas sector; b) the Estremoz-Barrancos sector and

\footnotetext{
1 Geobiotec, Dep. de Geociências, Univ. de Aveiro, 3810-193 Aveiro, Portugal. Email: ana.antunes@ua.pt
} 


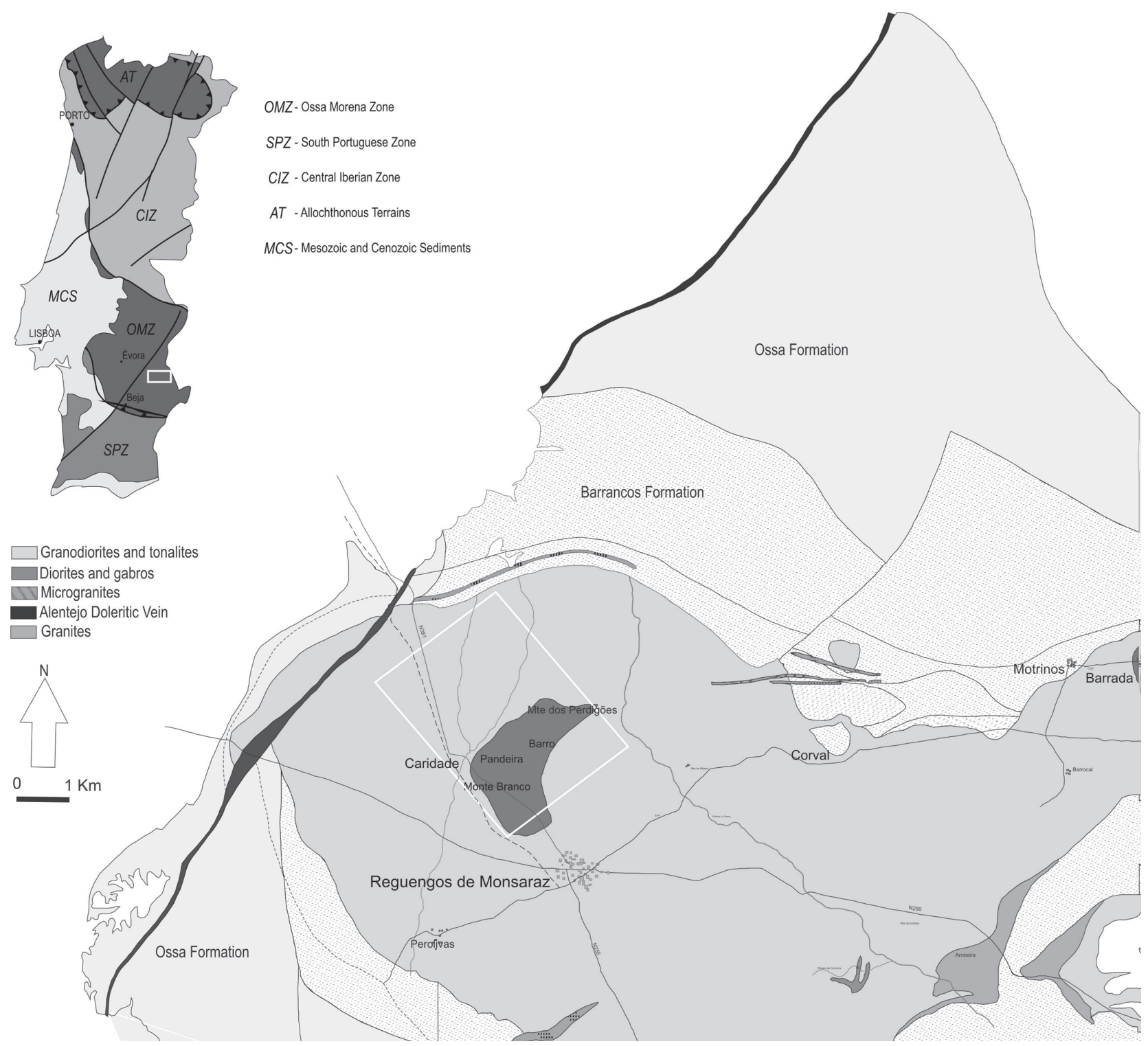

Fig. 1.-Simplified geological map of the Reguengos de Monsaraz Massif showing the location of the studied area in the Ossa Morena Zone.

c) the Montemor-Ficalho sector (Oliveira et al., 1991; Araújo et al., 2006). The studied area lies in the Estremoz-Barrancos Sector, close to the tectonic boundary (fault contact) with the Montemor-Ficalho Sector.

The Estremoz-Barrancos domain is characterized by the presence of Middle Cambrian to Lower Devonian sedimentary and vulcano-sedimentary sequences affected by two Variscan deformation phases. The main structures are NW-SE directed and the regional metamorphism does not generally exceed low grade conditions.

Carvalhosa \& Zbyzewski (1991) included the Reguengos de Monsaraz pluton in the group of the late- to post-tectonic granitoids. The intrusion has an irregular shape, but shows a $12 \mathrm{~km}$ long axis with an E-W orientation. It is essentially emplaced into a sequence of metapelites interlayered with 
metabasites from the Lower to Middle Ordovician Barrancos Formation. However, along its NE limit, the pluton intrudes a succession of metapsamites and metapelites of the Ossa Formation of probable Cambrian age. The massif is surrounded by a contact metamorphism aureole consisting mainly of pelitic hornfelses with andalusite, cordierite and/or sillimanite (Carvalhosa \& Zbyzewski, 1991).

The tonalites and the granodiorites are the dominant lithological types and contain abundant mafic microgranular enclaves (Carvalhosa, 1967 and Carvalhosa \& Zbyzewski, 1991). These authors also mentioned the occurrence of subordinate amounts of gabbro-dioritic rocks occupying the central part of the massif along an area with a maximum length of $3 \mathrm{~km}$. A biotite granite facies was also identified in the eastern sector of the pluton.

\section{Field relationships}

This work is focussed on the study of the gabbro-dioritic rocks and associated granitoids cropping out in the western sector of the Reguengos massif, between Reguengos de Monsaraz and Falcoeiras (Fig. 1).

A conspicuous mesoscopic feature observed during the field survey is the heterogeneous appearance of all the different lithological types. This is mainly due to the widespread occurrence of mafic microgranular enclaves within the tonalites and the granodiorites (Fig. 2), first mentioned by Carvalhosa \& Zbyzewski (1991). More recently, Silva \& Pinto (2006) reported the presence of heterogeneous dioritic facies with large biotite crystals, along the contact between the mafic central body and the surrounding granitoid lithologies. However, the heterogeneous appearance of the gabbro-dioritic rocks is not restricted to this contact and can be observed throughout the whole mafic body. It is marked by variations both in grain size and in modal composition and may result in the development of a layering of darker and lighter domains, visible at hand specimen scale. In most cases, the coexisting domains show diffuse limits, although the occurrence of tonalitic light-coloured pegmatoid veinlets and pockets with sharp boundaries has also been detected in some of the mafic rocks.

As a result of the scarcity and reduced extension of good exposures, it was not possible to define precisely the transition between the gabbro-dioritic body and the enclosing granitoids. However, the
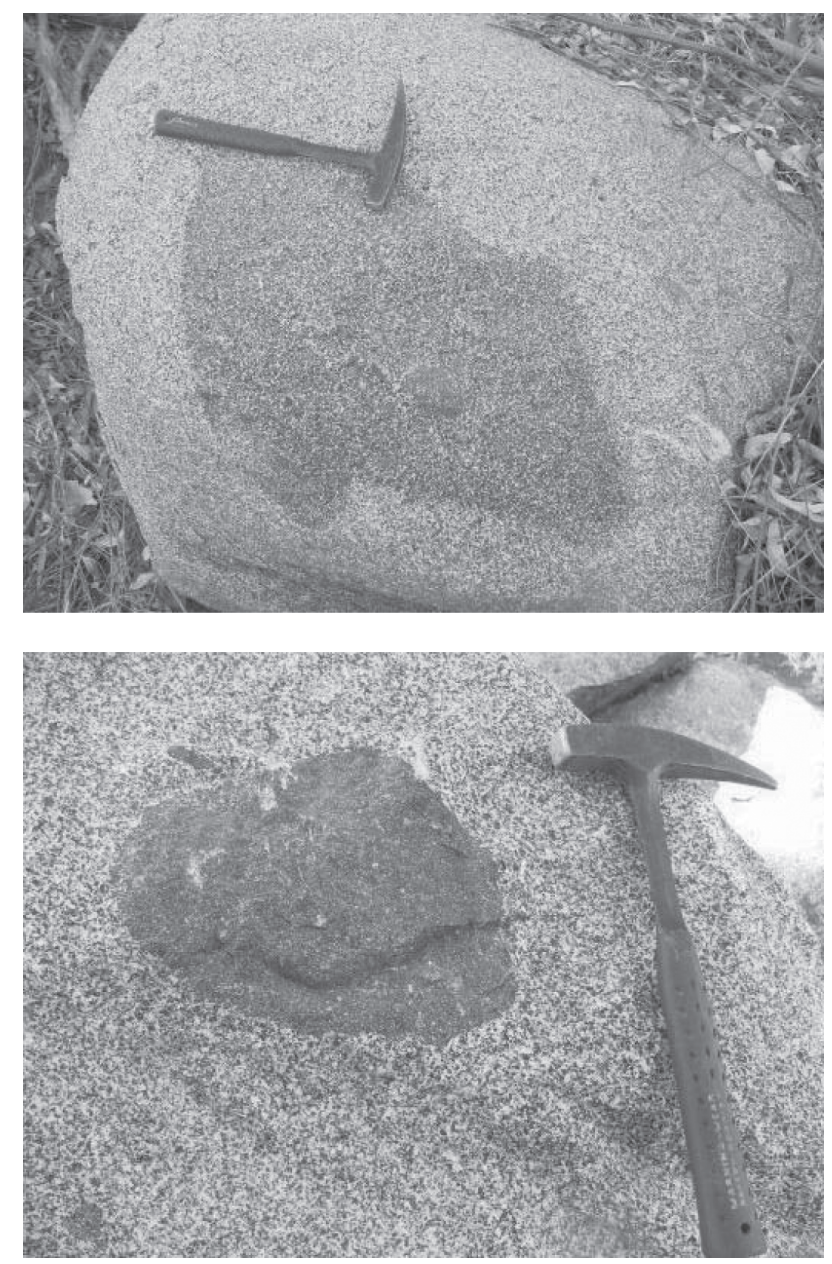

Fig. 2.-Aspect of mafic microgranular enclaves within tonalitic rocks.

field observations suggest that, rather than two independent magma pulses, the mafic and granitoid melts have been emplaced almost simultaneously and have mechanically (and chemically?) interacted before their complete crystallization.

\section{Petrography}

The textures of the different facies of the Reguengos de Monsaraz rmassif range from granular subhedral / anhedral to seriate. The former are predominant in the more homogeneous types, whereas the seriate textures tend to occur in the rocks and/or domains where the mesoscopic heterogeneity is conspicuous. 

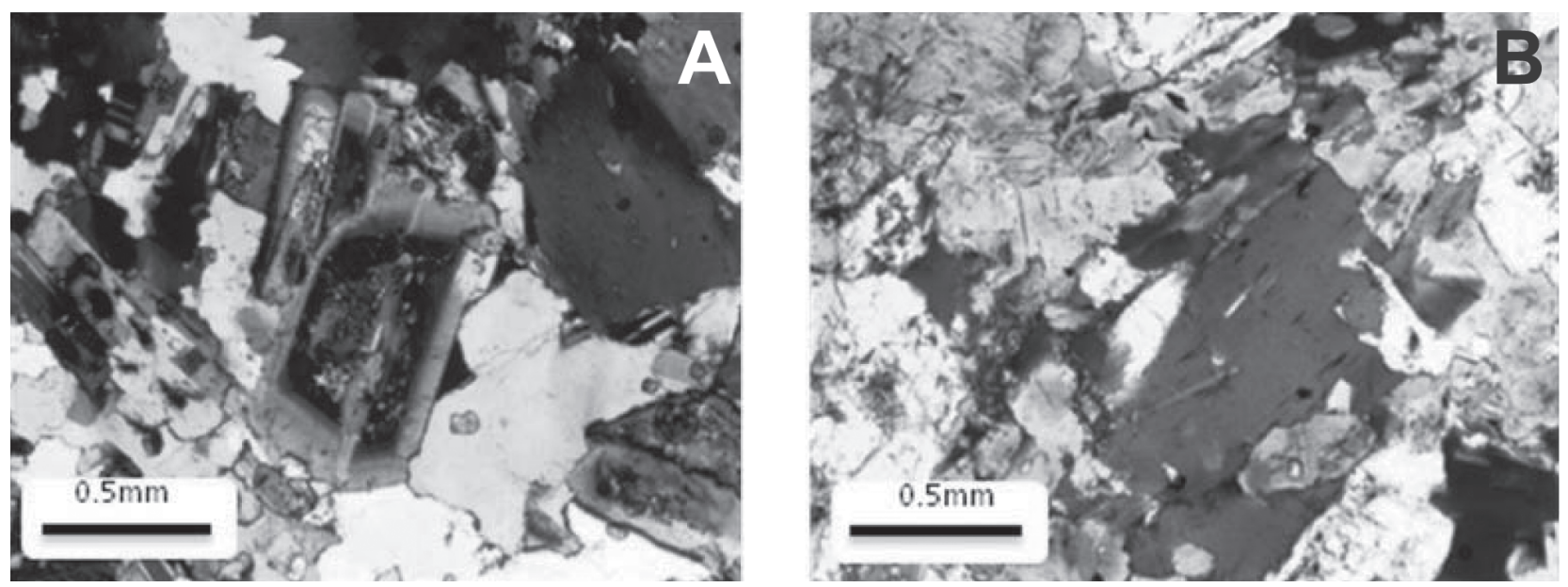

Fig. 3.-Microphotographs showing some textural aspects: a) Plagioclase zoning in tonalitic rock; b) Intergrowth between amphibole and biotite in diorite.

In terms of mineralogical composition, the sequence displays a gradual increase of microcline and quartz proportions and decrease of mafic mineral contents (specially, amphibole), from the gabbro-diorites to the tonalites and the granodiorites. These variations are accompanied by a consistent increase of the albite component in the plagioclase. Therefore, in agreement with the field evidence, there is a complete range of modal compositions between the least and the most evolved members of the intrusion. It should be noted that, at mesoscopic scale, the gabbro-dioritic body may include diffuse patches of quartz-dioritic and tonalitic rocks and, conversely, small mafic domains can be found within the more felsic facies.

Plagioclase is the major rock forming mineral in all lithological types and occurs in grains of several shapes and sizes with well defined zoned patterns (Fig. 3a) that may vary from normal and continuous to complex and, locally, truncated. In the gabbrodiorites, the cores of the zoned grains are generally highly calcic, reaching bytownite compositions $\left(\mathrm{An}_{83}\right)$, whilst the rims and the smaller groundmass crystals exhibit lower anortite contents (down to $\left.\mathrm{An}_{40}\right)$. On the other hand, andesine dominates in the tonalitic and granodioritic rocks and may attain compositions close to oligoclase in some granodiorite types. Labradorite was found in the cores of a few zoned crystals from these facies.

The presence of abrupt compositional discontinuities within single plagioclase grains betrays a failure of the silicate melts to attain perfect equilibrium with its solid phases and has been attributed by many authors to drastic changes in the crystallization conditions during magma mixing/mingling events (e.g. Vernon, 1990; Barbarin, 1990; Pitcher, 1993).

Quartz is present in almost all facies, even in the more basic, as anhedral crystals, filling the spaces between the other major mineral grains. K-feldspar is also a late stage interstitial phase, but occurs in a more restricted compositional range (quartzo-diorites-granodiorites). Its importance increases towards the granodiorite terms. The K-feldspar crystals show the microcline cross-hatch twinning and may develop an incipient poikilitic texture, enclosing plagioclase, amphibole and biotite.

Amphibole and biotite are the main ferromagnesian minerals within the whole spectrum of the Reguengos de Monsaraz rock types (Fig. 3b). The dominant amphibole is green to brownish-green hornblende and tends to form isolated subhedral grains, frequently associated with biotite. However, amphibole may also occur in aggregates of very small grains of green to pale green actinolitic hornblende, which appears to result from recrystallization of primary hornblende crystals. The gabbrodioritic lithologies have often zoned amphibole crystals with colourless cummingtonite-grunerite in the cores and hornblende in the rims.

Biotite is present as subhedral flakes in all the lithologies. Apatite, opaques (magnetite and ilmenite) and zircon are common accessory minerals, occurring frequently as inclusions within biotite and amphibole. Single, zoned grains of allanite with rounded shapes have also been sporadically found in the different members of the Reguengos de Monsaraz intrusion. 


\section{Analytical methods}

Twenty three representative samples of various intrusive units from the Reguengos de Monsaraz massif have been analysed for major and trace elements at Actlabs Ancaster, Ontario, Canada. The major elements were determined using Inductively Coupled Plasma Atomic Emission (ICP-AES) whilst the trace elements were analysed by Plasma Mass Spectrometry (ICP-MS), after alkaline melting with lithium metaborate/tetraborate followed by nitric acid dissolution. The major-, trace- and rareearth element data are presented in Table 1.

The $\mathrm{Rb}-\mathrm{Sr}$ isotopic analyses were performed on a VG SECTOR 54 multicollector thermal ionization mass spectrometer (TIMS) in the Laboratory of Isotope Geology of the University of Aveiro, Portugal (LGI-UA). $\mathrm{Rb}$ and $\mathrm{Sr}$ contents were determined by isotope dilution at LGI-UA. The analytical data were corrected for mass fractionation using an exponential law $\left({ }^{86} \mathrm{Sr} /{ }^{88} \mathrm{Sr}=0.1194\right)$. Average levels of blanks for $\mathrm{Sr}$ were in the range 0.25-1.0 ng. The standard NBS-987 gave a repeated value of $0.710254 \pm 34$ for (2sd of 49 analyses) during the period of analysis. Regression lines have been calculated using the least-squares method of York (1969) as implemented in the Isoplot program (Ludwig, 2003). The results are shown in Table 2.

\section{Geochemistry}

Taken together, the samples of the Reguengos de Monsaraz massif show a continuous compositional range $\left(\mathrm{SiO}_{2}=47.34-68.55 \%\right)$ from the least to the most evolved members of the suite. In the R1-R2 diagram (La Roche et al., 1980), the mafic terms plot in the fields of the olivine-gabbros, gabbros, gabbronorites and diorites whilst the felsic types fall essentially within the tonalite and granodiorite domains. The apparent discordance between the modal and the chemical classification schemes for the basic rocks may, at least in part, result from the fact that the nomenclature system used in the R1-R2 diagram is based on anhydrous mineralogy. As such, it is likely that the lack of olivine and pyroxene in the mafic terms and the high proportions of hydrous ferromagnesian silicates (amphibole and biotite) have, to some extent, disguised the basic nature of these lithologies, shifting the petrographic classification towards less basic compositions.

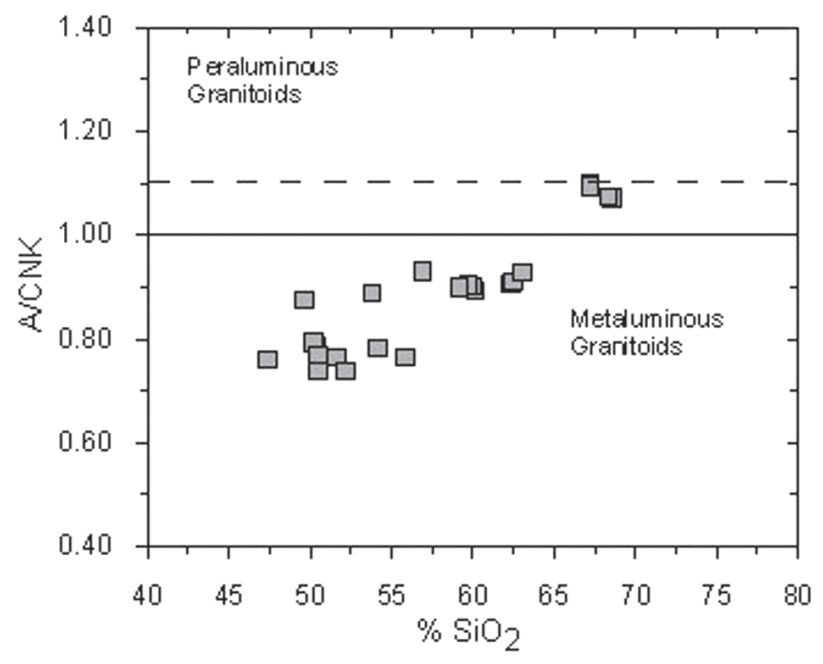

Fig. 4.-A/CNK vs. $\mathrm{SiO}_{2}$ diagram.

As expected from their mineralogical signatures, the degree of aluminosity in the different members of the sequence tends to increase with increasing $\mathrm{SiO}_{2}$ contents $(\mathrm{A} / \mathrm{CNK}=0.738-1.098$; Fig. 4$)$ and the majority of the analysed samples are clearly metaluminous. Only the most differentiated rock types exhibit a slight peraluminous character.

The presence of well defined linear correlations in most Harker variation diagrams suggests that magma mixing may have played an important role in the evolution of these rocks. In this scenario, the consistent decrease in $\mathrm{Fe}_{2} \mathrm{O}_{3} \mathrm{t}, \mathrm{MgO}, \mathrm{MnO}, \mathrm{CaO}$, $\mathrm{TiO}_{2}$ and $\mathrm{Sc}$ and increase in $\mathrm{K}_{2} \mathrm{O}, \mathrm{Na}_{2} \mathrm{O}, \mathrm{Rb}$, Th and $\mathrm{U}$ with progressively higher $\mathrm{SiO}_{2}$ values could be attributed to the chemical interaction between melts of contrasting compositions (Figs. 5 and 6). The lack of curvilinear trends for elements (such as magnesium) that are easily incorporated in the early forming mineral phases during fractional crystallization provides strong evidence in favour of a petrogenetic model involving magma mixing as the dominant diversification mechanism. This does not necessarily preclude a minor contribution of fractional crystallization to the observed compositional trends.

At first sight, the highly scattered variation patterns displayed by some trace elements (e.g., Zr, Hf, REE) would tend to rule out the proposed interpretation. It should be stressed, however, that the behaviour of these elements is strongly controlled by accessory minerals like zircon ( $\mathrm{Zr}$, Hf) and allanite (REE). Small differences in the modal amounts of these phases may therefore have drastic effects in 
Table 1.-Whole-rock composition of the studied samples

\begin{tabular}{|c|c|c|c|c|c|c|c|c|c|c|}
\hline & $\begin{array}{c}\text { RMS } \\
2\end{array}$ & $\begin{array}{c}\text { RMS } \\
5\end{array}$ & $\begin{array}{c}\text { RMS } \\
7\end{array}$ & $\begin{array}{c}\text { RMS } \\
8\end{array}$ & $\begin{array}{c}\text { RMS } \\
10\end{array}$ & $\begin{array}{c}\text { RMS } \\
11\end{array}$ & $\begin{array}{c}\text { RMS } \\
15\end{array}$ & $\begin{array}{c}\text { RMS } \\
16\end{array}$ & $\begin{array}{c}\text { RMS } \\
17\end{array}$ & $\begin{array}{c}\text { RMS } \\
18\end{array}$ \\
\hline $\mathrm{SiO}_{2}$ & 53.8 & 67.22 & 68.55 & 68.35 & 47.34 & 50.4 & 56.86 & 49.65 & 60.17 & 62.31 \\
\hline $\mathrm{TiO}_{2}$ & 0.942 & 0.382 & 0.372 & 0.376 & 1.135 & 1.105 & 0.882 & 1.054 & 0.743 & 0.639 \\
\hline $\mathrm{Al}_{2} \mathrm{O}_{3}$ & 18.37 & 15.87 & 15.7 & 15.64 & 17.3 & 16.67 & 17.29 & 17.12 & 15.73 & 15.59 \\
\hline $\mathrm{Fe}_{2} \mathrm{O}_{3}(\mathrm{t})$ & 8.81 & 3.49 & 3.27 & 3.33 & 11.06 & 9.67 & 7.68 & 10.2 & 6.36 & 5.57 \\
\hline $\mathrm{MnO}$ & 0.158 & 0.06 & 0.066 & 0.069 & 0.177 & 0.165 & 0.131 & 0.175 & 0.111 & 0.098 \\
\hline $\mathrm{MgO}$ & 4.52 & 1.06 & 0.85 & 0.88 & 6.6 & 6.22 & 3.84 & 6.02 & 4.31 & 3.34 \\
\hline $\mathrm{CaO}$ & 8.27 & 2.73 & 2.71 & 2.74 & 10.08 & 9.05 & 7 & 7.99 & 5.99 & 5.46 \\
\hline $\mathrm{Na}_{2} \mathrm{O}$ & 2.39 & 3.69 & 3.56 & 3.5 & 1.64 & 1.74 & 2.33 & 1.78 & 2.43 & 2.52 \\
\hline $\mathrm{K}_{2} \mathrm{O}$ & 1.57 & 3.16 & 3.58 & 3.54 & 1.62 & 1.79 & 1.87 & 1.94 & 2.54 & 2.91 \\
\hline $\mathrm{P}_{2} \mathrm{O}_{5}$ & 0.22 & 0.16 & 0.17 & 0.17 & 0.27 & 0.24 & 0.17 & 0.22 & 0.14 & 0.14 \\
\hline Loss & 0.79 & 1.15 & -0.34 & 0.66 & 1.13 & 1.26 & 0.96 & 2.32 & 1.01 & 0.79 \\
\hline Total & 99.83 & 98.97 & 98.48 & 99.25 & 98.33 & 98.31 & 99.02 & 98.47 & 99.54 & 99.36 \\
\hline $\mathrm{Rb}$ & 52 & 113 & 144 & 138 & 51 & 56 & 71 & 68 & 113 & 115 \\
\hline $\mathrm{Sr}$ & 235 & 169 & 166 & 161 & 206 & 192 & 209 & 204 & 176 & 160 \\
\hline $\mathrm{Ba}$ & 298 & 592 & 549 & 534 & 382 & 407 & 425 & 746 & 665 & 566 \\
\hline Y & 25.3 & 26.8 & 25.7 & 24.4 & 38.5 & 45.2 & 23.9 & 42.3 & 14.4 & 25.8 \\
\hline $\mathrm{Zr}$ & 152 & 152 & 178 & 156 & 159 & 142 & 136 & 119 & 165 & 182 \\
\hline $\mathrm{Nb}$ & 14 & 11.6 & 14 & 13.1 & 15.3 & 15.4 & 13 & 12.9 & 9.9 & 11.9 \\
\hline Th & 4.29 & 10.2 & 12.1 & 11.5 & 2.24 & 3.88 & 4.98 & 2.5 & 6.64 & 11 \\
\hline $\mathrm{La}$ & 24.5 & 36.4 & 36.1 & 34.6 & 27.5 & 27.9 & 24.1 & 27 & 23.2 & 30 \\
\hline $\mathrm{Ce}$ & 48.5 & 69.5 & 72.4 & 66.6 & 63.6 & 66.1 & 46.7 & 63.8 & 41.6 & 58.1 \\
\hline $\mathrm{Nd}$ & 20.4 & 25.3 & 27.4 & 23.8 & 30.7 & 33.1 & 19.4 & 31.5 & 13.4 & 21.5 \\
\hline $\mathrm{Sm}$ & 4.61 & 5.46 & 5.39 & 4.95 & 7.26 & 8.08 & 4.47 & 7.77 & 2.73 & 4.7 \\
\hline $\mathrm{Eu}$ & 1.25 & 1.08 & 1.01 & 0.93 & 1.82 & 1.65 & 1.24 & 1.68 & 1.02 & 1 \\
\hline $\mathrm{Tb}$ & 0.81 & 0.76 & 0.73 & 0.78 & 1.15 & 1.48 & 0.7 & 1.23 & 0.4 & 0.81 \\
\hline $\mathrm{Yb}$ & 2.44 & 2.52 & 2.36 & 2.29 & 3.69 & 4.19 & 2.24 & 4.11 & 1.58 & 2.46 \\
\hline
\end{tabular}

Table 2.- Rb-Sr isotopic data for whole rock and minerals (sample: Ossa 32B)

\begin{tabular}{lccclcl}
\hline \multicolumn{1}{c}{ Sample } & $\mathrm{Rb}$ & $\mathrm{Sr}$ & ${ }^{87} \mathrm{Rb} /{ }^{86} \mathrm{Sr}$ & Erro & ${ }^{87} \mathrm{Sr} /{ }^{86} \mathrm{Sr}$ & \multicolumn{1}{c}{ Error } \\
\hline Whole rock & 118 & 145 & 2.357 & 0.067 & 0.719830 & 0.000045 \\
Biotite & 507 & 6.37 & 252.5 & 3.2 & 1.69113 & 0.00012 \\
Feldspar & 43.3 & 66.1 & 1.898 & 0.021 & 0.715696 & 0.000054 \\
Amphibole & 205 & 13.57 & 44.51 & 0.42 & 0.896109 & 0.000068 \\
\hline
\end{tabular}

their contents, obscuring the potential correlations with the differentiation index.

The chondrite normalized REE patterns shown in Figure $7 \mathrm{a}$ are characterized by a moderate enrichment in LREE $\left(4.71 \leq \mathrm{La}_{\mathrm{N}} / \mathrm{Yb}_{\mathrm{N}} \leq 10.98\right)$ and the presence of negative $\mathrm{Eu}$ anomalies of variable magnitude $\left(0.54 \leq \mathrm{Eu} / \mathrm{Eu}^{*} \leq 0.85\right)$. Only one diorite sample displays an $\mathrm{Eu} / \mathrm{Eu}^{*}$ ratio of 1.18 . In the multi-element diagrams, normalized to the composition of primordial mantle, the analysed samples exhibit moderate to high LILE/HFSE ratios $\left(\mathrm{Rb}_{\mathrm{N}} / \mathrm{Yb}_{\mathrm{N}}=7.48-55.53\right)$ and well defined $\mathrm{Nb}$ and Ta depressions (Fig. 7b). The trace element patterns, in conjunction with the metaluminous character of the suite, demonstrate that all the members of the Reguengos de Monsaraz intrusion were derived from magmas of typical calc-alkaline nature.
Based on the available geochemical data, it may be further suggested that the different rock types from the Reguengos de Monsaraz massif are genetically related and constitute a coherent intrusive suite produced by extensive interaction between basic and acid magmas. This would account for both the compositional continuity of the series and the complex field, mineralogical and textural relationships between the gabbro-dioritic rocks, the host tonalites and granodiorites and the mafic microgranular enclaves.

The distinctive calc-alkaline signature of the whole suite appears to indicate that, at low crustal levels, magma mixing may have not been the dominant petrogenetic mechanism and that the more evolved compositions could have been largely produced by fractional crystallization of mantle derived 


\begin{tabular}{|c|c|c|c|c|c|c|c|c|c|c|c|}
\hline $\begin{array}{c}\text { RMS } \\
19\end{array}$ & $\begin{array}{c}\text { RMS } \\
20\end{array}$ & $\begin{array}{c}\text { RMS } \\
22\end{array}$ & $\begin{array}{c}\text { RMS } \\
23\end{array}$ & $\begin{array}{c}\text { RMS } \\
24\end{array}$ & $\begin{array}{c}\text { RMS } \\
27\end{array}$ & $\begin{array}{c}\text { RMS } \\
28\end{array}$ & $\begin{array}{c}\text { RMS } \\
29\end{array}$ & $\begin{array}{c}\text { RMS } \\
33\end{array}$ & $\begin{array}{c}\text { RMS } \\
35\end{array}$ & $\begin{array}{c}\text { RMS } \\
36\end{array}$ & $\begin{array}{c}\text { RMS } \\
37 \mathrm{~A}\end{array}$ \\
\hline 51.61 & 50.49 & 52.15 & 50.2 & 50.48 & 55.82 & 54.15 & 62.48 & 59.93 & 67.22 & 59.73 & 59.17 \\
\hline 1.042 & 1.016 & 0.814 & 1.014 & 1.05 & 0.793 & 0.855 & 0.637 & 0.717 & 0.424 & 0.699 & 0.698 \\
\hline 16.22 & 16.27 & 15.73 & 17.27 & 16.87 & 15.25 & 16.75 & 15.78 & 15.51 & 16.19 & 16.04 & 16.07 \\
\hline 9.6 & 11.17 & 9.91 & 10.09 & 10.15 & 8.41 & 9.07 & 5.54 & 6.06 & 3.52 & 6.31 & 6.39 \\
\hline 0.148 & 0.166 & 0.174 & 0.163 & 0.163 & 0.151 & 0.152 & 0.099 & 0.105 & 0.046 & 0.107 & 0.108 \\
\hline 6.06 & 6.7 & 6.31 & 6.08 & 6.06 & 5.98 & 5.71 & 3.26 & 4.13 & 1.06 & 4.09 & 4.09 \\
\hline 8.97 & 9.7 & 9.11 & 9.43 & 9.51 & 7.71 & 8.8 & 5.49 & 5.74 & 2.81 & 6.05 & 6.16 \\
\hline 1.81 & 1.88 & 1.9 & 1.78 & 1.77 & 2.16 & 2.25 & 2.5 & 2.39 & 3.57 & 2.41 & 2.39 \\
\hline 1.79 & 1.24 & 1.5 & 1.6 & 1.59 & 2.18 & 1.6 & 2.99 & 2.6 & 3.52 & 2.59 & 2.52 \\
\hline 0.23 & 0.23 & 0.16 & 0.19 & 0.22 & 0.17 & 0.19 & 0.14 & 0.13 & 0.16 & 0.13 & 0.13 \\
\hline 1.52 & 1.1 & 1.05 & 1.13 & 1.48 & 1.02 & 0.98 & 0.79 & 0.94 & 0.88 & 1.09 & 0.96 \\
\hline 99.00 & 99.96 & 98.82 & 98.94 & 99.33 & 99.66 & 100.5 & 99.69 & 98.26 & 99.39 & 99.24 & 98.67 \\
\hline 58 & 37 & 47 & 49 & 52 & 79 & 55 & 115 & 110 & 120 & 105 & 100 \\
\hline 175 & 197 & 188 & 194 & 189 & 160 & 188 & 166 & 170 & 175 & 185 & 188 \\
\hline 345 & 283 & 278 & 382 & 373 & 414 & 388 & 595 & 500 & 593 & 561 & 572 \\
\hline 40.9 & 39 & 33.3 & 34.9 & 35.3 & 42.3 & 36.7 & 24.3 & 20.5 & 30.5 & 26.1 & 26.4 \\
\hline 139 & 160 & 128 & 123 & 113 & 148 & 145 & 196 & 150 & 164 & 154 & 162 \\
\hline 14.3 & 15 & 12.4 & 12 & 13.5 & 12.6 & 13.1 & 11.7 & 10.3 & 11.5 & 10.4 & 10.2 \\
\hline 4.85 & 2.99 & 4.03 & 2.95 & 3.23 & 6.78 & 3.42 & 9.17 & 8 & 11.7 & 8.71 & 8.97 \\
\hline 27.3 & 27.6 & 24.9 & 26.2 & 23.8 & 29.6 & 26.5 & 27.8 & 26.4 & 39 & 26.3 & 25.9 \\
\hline 65.6 & 65 & 55.9 & 60.1 & 55.7 & 66.5 & 59.9 & 54.4 & 52.1 & 76.1 & 52.4 & 51.7 \\
\hline 31 & 29.6 & 25.1 & 27.7 & 25.7 & 31.8 & 27.2 & 21.2 & 18.6 & 28.3 & 20.7 & 20.4 \\
\hline 7.2 & 6.89 & 5.77 & 6.6 & 6.02 & 7.62 & 6.3 & 4.62 & 4.05 & 6.03 & 4.62 & 4.56 \\
\hline 1.5 & 1.59 & 1.32 & 1.61 & 1.46 & 1.35 & 1.41 & 1.05 & 1.05 & 1.12 & 1.03 & 1.05 \\
\hline 1.26 & 1.12 & 0.95 & 0.99 & 1.01 & 1.17 & 1 & 0.71 & 0.58 & 0.87 & 0.75 & 0.77 \\
\hline 3.92 & 3.84 & 3.22 & 3.49 & 3.45 & 4.03 & 3.53 & 2.48 & 2.07 & 2.89 & 2.52 & 2.49 \\
\hline
\end{tabular}

basic magmas. In such a scenario, mixing would have essentially occurred during the ascent and emplacement of the co-existing mafic magmas and their differentiates (tonalites and granodiorites), masking the evidence of fractionation processes in Harker variation diagrams. However, it is possible that contamination and/or mixing with anatectic crustal melts could have occurred at some extent, explaining the slightly peraluminous character displayed by some of the more felsic samples.

\section{Geochronology}

The emplacement of the Reguengos de Monsaraz pluton was dated at about $372 \mathrm{Ma}(\mathrm{Rb}-\mathrm{Sr}$ whole-rock) and $340 \mathrm{Ma}(\mathrm{Rb}-\mathrm{Sr}$ biotite) by Mendes (1967-1968) and Pinto (1984). Given the late to post-tectonic character of the massif, inferred from geological evidence, it is possible that these ages are fictitious and do not record the time of original crystallization. The potential involvement of geochemically and isotopically distinct components in the genesis of the suite may be invoked to explain the 372 Ma whole-rock pseudo-isochron, as complete isotopic homogenization is rarely attained during mixing and frequently results in anomalous old "ages". On the other hand, the $\mathrm{Rb}-\mathrm{Sr}$ age provided by biotite separates $(\approx 340 \mathrm{Ma})$ suggests that the $\mathrm{Sr}$ isotopic composition of this mineral phase may have been strongly disturbed during magmatic and/or late stage hydrothermal processes.

More recently, Silva \& Pinto (2006) obtained a $312 \pm 60 \mathrm{Ma}$ whole-rock "isochron" for five samples of the tonalites and granodiorites from Reguengos de Monsaraz (MSWD $=18 ;{ }^{87} \mathrm{Sr} /{ }^{86} \mathrm{Sr}_{\text {initial }}=$ $0.7096 \pm 0.0015)$. In view of its very high MSWD, the $312 \mathrm{Ma}$ errorchron cannot be taken as an intrusion age and may again correspond to a "mixing line".

In this work, one whole rock granodiorite sample and separates from three mineral phases (biotite, amphibole and feldspar) were chosen for Rb-Sr dating. The four points define an errorchron of $273 \pm 14 \mathrm{Ma}$ $\left({ }^{87} \mathrm{Sr} /{ }^{86} \mathrm{Sr}_{\text {inicial }}=0.714 \pm 0.022 ; \mathrm{MSWD}=165\right)$ which is significantly younger than expected from regional constraints (Fig. 6a). As the slope of the errorchron is strongly controlled by the biotite ${ }^{87} \mathrm{Sr} /{ }^{86} \mathrm{Sr}$ ratio and this mineral phase is highly sensitive to sub-solidus alteration, the age was recalculated using only the 

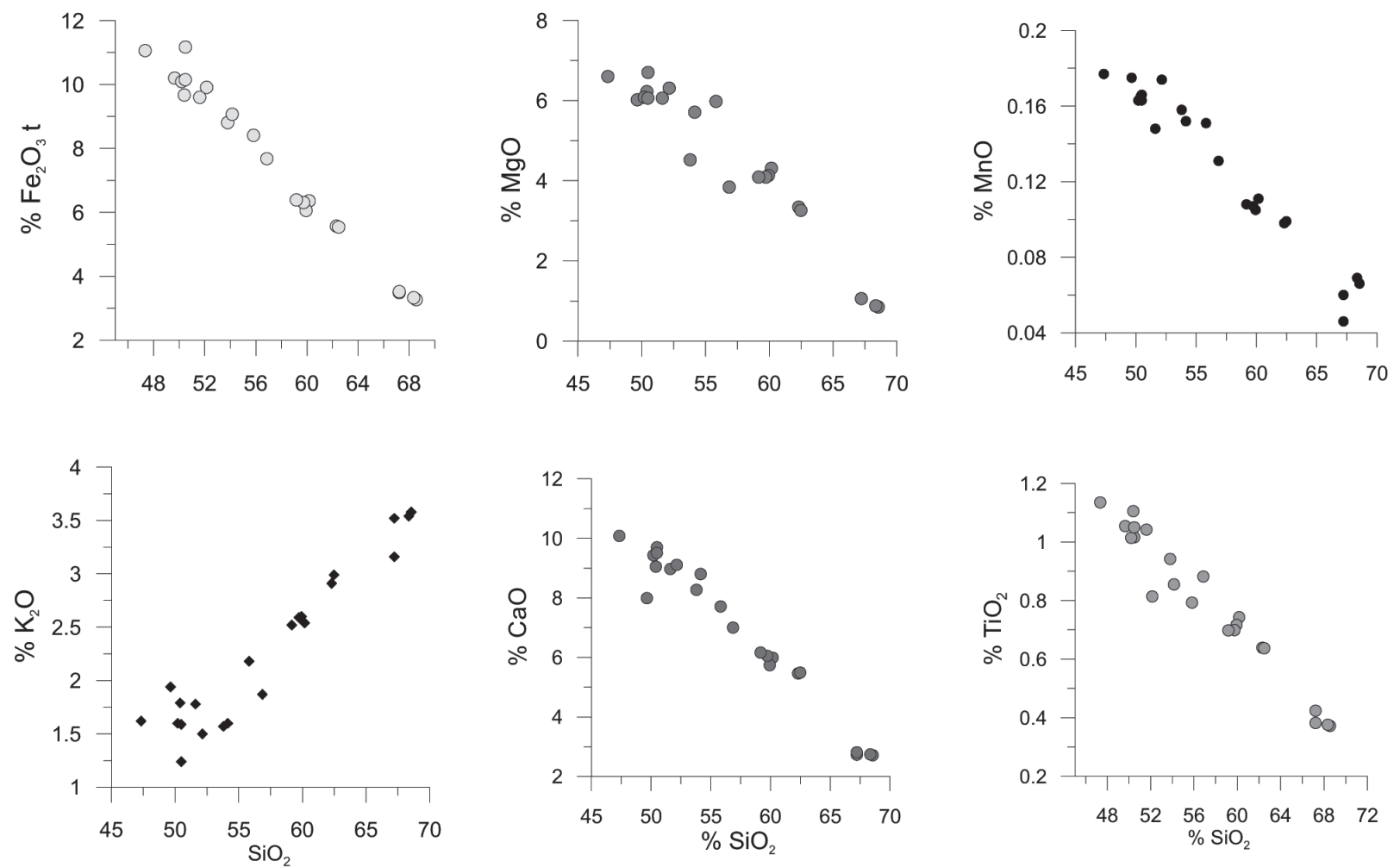

Fig. 5.- Harker variation diagrams for some major element oxides.
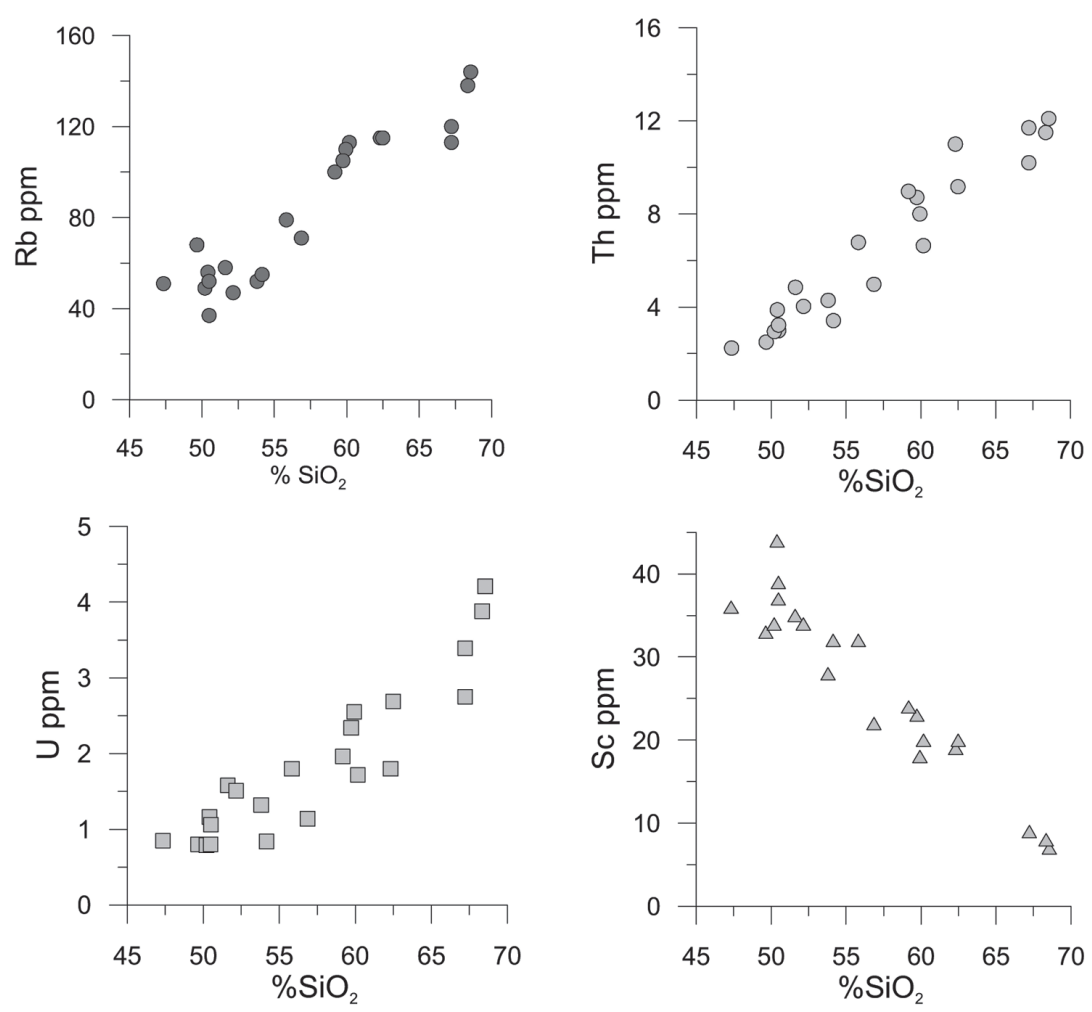

Fig. 6.-Harker variation diagrams for some trace elements. 

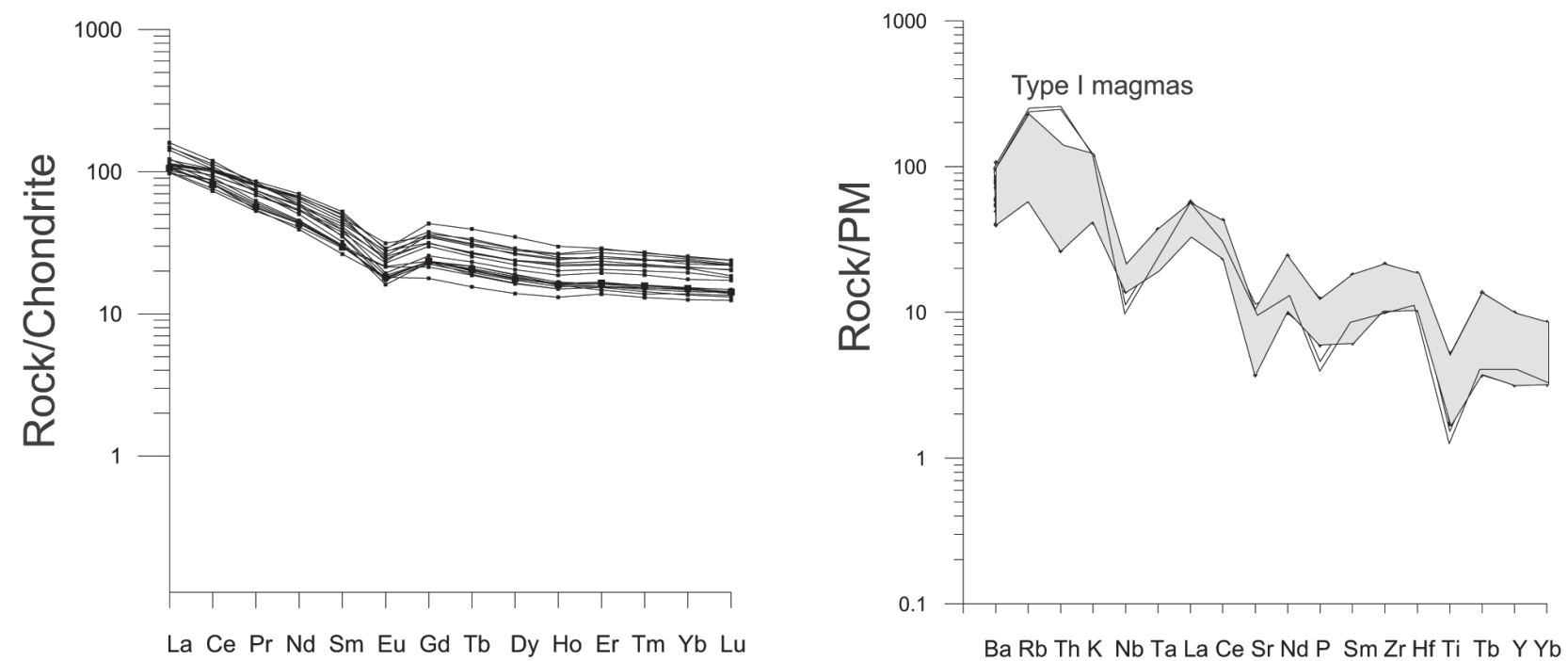

Fig. 7.-Left: REE chondrite-normalized patterns. Right: Primordial mantle normalized multielemental diagrams. Normalization constants from Evensen (1978) and Sun \& McDonough (1989).

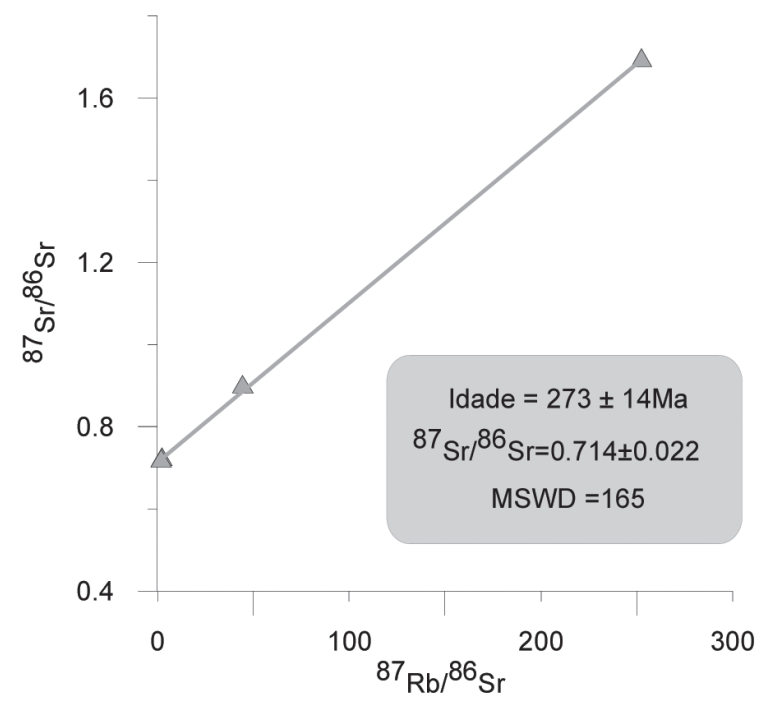

Fig. 8.-Isochron Rb-Sr: (left) RT-Bt-Fsp-Anf; (right) Fsp-Anf.

feldspar-amphibole pair. The results are shown in Figure $8 \mathrm{~b}$ and yielded an "age" of $297.5 \pm 2.9 \mathrm{Ma}$ $\left.{ }^{87} \mathrm{Sr} /{ }^{86} \mathrm{Sr}_{\text {initial }}=0.70766 \pm 0.00011\right)$. This date is interpreted here as a cooling age, following igneous crystallization. However, it appears to provide a minimum age constraint for the emplacement of these rocks because their shallow intrusion level would tend to rule out a long cooling history. The lack of evidence for younger events of metamorphism and ductile deformation in the region reinforces the proposed interpretation.

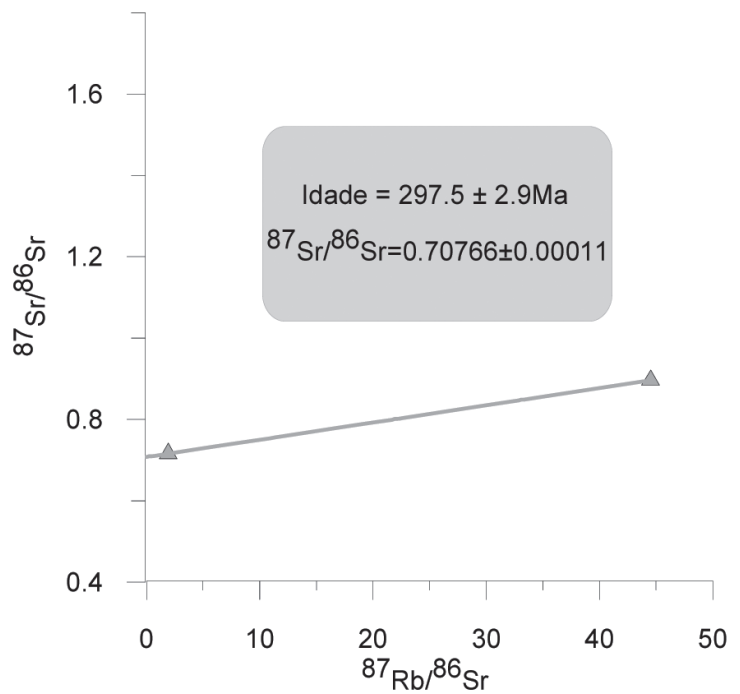

\section{Conclusions}

The main conclusions of the present investigation can be summarized as follows:

- All the lithologies of the Reguengos de Monsaraz massif show conspicuous textural and mineralogical heterogeneities, at mesoscopic scale, marked by the widespread occurrence of mafic microgranular enclaves throughout the dominant granitoid types and the presence of irregular patches of quartz-dioritic and tonalitic composition within 
the gabbro-diorites. As a result, the different facies are frequently interpenetrated and define diffuse contact relationships.

- This variability is also expressed in thin section by the development of seriate textures, the wide range of plagioclase zoned patterns and compositions and the uneven spatial distribution of K-feldspar.

- The results of major and trace element geochemistry reveal that all the members of the suite are genetically related and display distinctive calcalkaline affinities. An origin involving fractional crystallization of mantle derived magmas, at deep crustal levels, followed by mixing/mingling during ascent and emplacement is proposed to account for the observed geochemical variation. At the presently exposed level, the effects of fractional crystallization appear to have been strongly obliterated by the subsequent mixing phenomena.

- The slightly peraluminous character displayed by some of the more felsic samples may have resulted from contamination and/or mixing with anatectic crustal melts, although these mechanisms appear to have played a very minor role in the petrogenesis of the suite.

- The $\mathrm{Rb}-\mathrm{Sr}$ isotopic data obtained in this work for a feldspar-amphibole pair from one granodiorite sample yielded an age of $297.5 \pm 2.9 \mathrm{Ma}$. This value is interpreted as a cooling age, but provides a minimum estimate for the timing of magmatic crystallization and falls well within the range of ages obtained for the group of late to post-tectonic granitoids from the OMZ.

In order to refine and test the proposed model, it is fundamental to enlarge the field, petrographic, geochemical and isotopic data base, particularly in what concerns the collection of samples from other sectors of the massif and the acquisition of new information on mineral chemistry, $\mathrm{Sr}-\mathrm{Nd}$ isotopic compositions and $\mathrm{U}-\mathrm{Pb}$ geochronology.

\section{References}

Araújo, A.; Piçarra Almeida, J.; Borrego, J.; Pedro, J. \& Oliveira, T. (2006). As regiões central e sul da Zona de Ossa Morena. In: Geologia de Portugal no Contexto da Ibéria (Dias, R.; Araújo, A.; Terrinha, P. \& Kullberg, J.C., eds.), Universidade de Évora, 151-172.
Barbarin, B. (1990). Plagioclase xenocrysts and mafic magmatic enclaves in some granitoids of the Sierra Nevada batholith, California. Journal of Geophysical Research, 95: 17747-17756. doi:10.1029/JB095iB11p17747

Carvalhosa, A. (1967). Notícia Explicativa da Folha 40$D$ (Portel) da Carta Geológica de Portugal, na escala 1:50 000. Serv. Geol. de Portugal, Lisboa, 24 pp.

Carvalhosa, A. \& Zbyzewski, G. (1991). Notícia Explicativa da Folha 40-B (Reguengos de Monsaraz) da Carta Geológica de Portugal, na escala 1:50000. Serviços Geologicos de Portugal, Lisboa, $51 \mathrm{pp}$.

Evensen, N.H.; Hamilton, P.J. \& O’Nions, R.K. (1978). Rare earth abundances in chondrite meteorites. Geochimica et Cosmochimica Acta, 42: 1199-1212. doi:10.1016/0016-7037(78)90114-X

La Roche, H.; Leterrier, J.; Granclaude, P. \& Marchal, M. (1980). A classification of volcanic and plutonic rocks using R1-R2 diagram and major elements analysis. Chemical Geology, 29: 183-210. doi:10.1016/0009-2541(80)90020-0

Mendes, F. (1967-68) Contribuition à l'étude geochronologique par la méthode du strontium des formations cristalines du Portugal. Boletin do Museu e Laboratório Mineralógico e Geológico da Faculdade de CiênciasUniversidade de Lisboa, 2: 3-157.

Oliveira, J.T.; Oliveira, V. \& Piçarra, J.M. (1991). Traços gerais da evolução tectono-estratigráfica da Zona de Ossa Morena em Portugal: síntese crítica do estado actual dos conhecimentos. Comunicações dos Serviços Geológicos de Portugal, 77: 3-26.

Pinto, M.S. (1984). Granitóides caledónicos e hercínicos na Zona de Ossa Morena (Portugal)- nota sobre aspectos geocronológicos. Memórias e Notícias, Publicações do Museu e Laboratório Mineralógico e Geológico da Universidade de Coimbra, 97: 81-94.

Pitcher, W.S. (1993). The nature and origin of granite. Chapman \& Hall, London, $321 \mathrm{pp}$.

Silva, M.M.V.G. \& Pinto, M.M.S.C. (2006). Geoquímica das rochas ígneas do plutão de Reguengos de Monsaraz (Alto Alentejo). Livro de resumos do VII Congresso Nacional de Geologia, 1: 249-251.

Sun, S. \& Mc Donough, W.F. (1989). Chemical and isotopic systematics of oceanic basalts: implications for mantle composition and processes. In: Magmatism in the Ocean Basins (Saunders, A.D. \& Norry, M.J., eds.). Geological Society of London Special Publications, London, 42: 313-345.

Vernon, R.H. (1990). Crystallization and hybridism in microgranitoid enclave magmas: microstructural evidence. Journal of Geophysical Research, 95: 1784917859. doi:10.1029/JB095iB11p17849

Recibido el 15 de diciembre de 2009 Aceptado el 25 de marzo de 2010 Publicado online el 5 de mayo de 2010 